\title{
PENGENDALIAN PENYAKIT JAMUR AKAR PUTIH (JAP) PADA TANAMAN KARET RAKYAT DENGAN FUNGISIDA HAYATI JAMUR ANTAGONIS Trichoderma spp.
}

\section{BIOLOGICAL CONTROL OF WHITE ROOT DISEASE IN FOLK RUBBER PLANTATION BY FUNGI ANTAGONISTIC Trichoderma spp.}

\author{
Oleh: \\ Morina Adfa ${ }^{1}$, Welly Darwis ${ }^{2}$, Irfan Gustian ${ }^{1}$, dan Hendri Bustamam ${ }^{3}$ \\ ${ }^{1}$ Jurusan Kimia, Fakultas MIPA, Universitas Bengkulu \\ ${ }^{2}$ Jurusan Biologi, Fakultas MIPA, Universitas Bengkulu \\ ${ }^{3}$ Jurusan Ilmu Hama dan Penyakit Tumbuhan, Fakultas Pertanian, Universitas Bengkulu \\ Corresponding Author: morinaadfa@yahoo.com
}

\begin{abstract}
The main problem in the people's rubber in the village of Genting Perangkap and Lubuk Balam, Air Besi, North Bengkulu is a fungal disease that attacks the roots of plants. White root fungus disease (JAP) cause of death in rubber, so that the disease attacks resulted in significant losses. Based on field survey team PPM to land smallholder rubber of Genting Perangkap and Lubuk Balam Village, many found the plants spaces are very close, the stump of a dead rubber tree attacked JAP left alone on the land, and the plants die immediately replaced with new seedlings without eradicate exhausted dead tree stump by JAP. As a result of this new plant will die after the age of 2 years or more, since contracted directly by the fungi Rigidoporus microporus that cause disease JAP from the ground and fungal spores contained in the rubber tree stumps that had not been cleaned. To help the problems of rubber farmers in the village of Genting Perangkap and Lubuk Balam, it is necessary to control training and extension activities of white root fungus disease (JAP) on smallholder rubber plant with a fungicide biological antagonist fungus Trichoderma spp. and the efforts of former rubber plantation land processing stricken JAP. The method used is counseling, training, and applications directly to the field. Having done this activity then: Service target communities have been able to recognize the early symptoms of fungal disease attacks the roots of white, rubber plant spacing was good, as well as the handling of the former rubber plantation land that was attacked by JAP. Target communities have learned how to control the disease by using the JAP antagonist fungus Trichoderma spp. Target communities already have the expertise and is able to reproduce itself Trichoderma spp. and how the application of the newly planted crops, and plants attacked JAP. The outcome of this IbM activity is the product of the fertilizer Trichoderma spp.
\end{abstract}

Keywords: Farmers, JAP, Rigidoporus microporus, Trichoderma spp. 


\section{PENDAHULUAN}

Tanaman karet merupakan salah satu komoditi andalan provinsi Bengkulu. Luas areal perkebunan karet di Bengkulu tahun 2011 adalah 73.747 Ha (Buku Statistik Perkebunan, 2012), atau sekitar 20,09\% dari seluruh areal perkebunan yang ada di Bengkulu dan merupakan peringkat ketiga setelah perkebunan Sawit dan Kopi. Nilai ekspor komoditas karet menempati peringkat pertama penyumbang devisa terbesar bagi Provinsi Bengkulu pada tahun 2009 yaitu sebesar 63,93 juta US\$ atau sebesar 58,59\%, kemudian diikuti komoditas batubara sebesar 40,7 juta US\$ atau 37,3\% dari penyumbang devisa Bengkulu (Gubernur Bengkulu-RKPD, 2012). Dari total areal tanaman karet yang ada di provinsi Bengkulu sebagian besar merupakan perkebunan rakyat, dan sisanya adalah perkebunan negara dan swasta, seperti contohnya perkebunan karet rakyat di Desa Genting Perangkap dan Desa Libuk Balam, Kecamatan Air Besi, Kabupaten Bengkulu Utara.

Desa Genting Perangkap terletak di Kecamatan Air Besi, Kabupaten Bengkulu Utara adalah sebuah desa dengan luas $\pm 3.000 \mathrm{Ha}$ dan berpenduduk sebanyak 316 jiwa yang terdiri dari $105 \mathrm{KK}$. Sebanyak 70\% penduduk merupakan usia produktif yang sebagian besar mata pencariannya adalah berkebun. Hampir 75\% dari luas Desa Genting Perangkap merupakan perkebunan karet usaha rakyat dan sebagian kecil perkebunan kopi (Muhammad dkk., 2012). Sama halnya dengan Desa Lubuk Balam, Desa yang berbatasan langsung dengan Desa Genting Perangkap, Kecamatan Air Besi, Kabupaten Bengkulu Utara, dengan luas yang hampir sama dengan Desa Genting Perangkap juga mempunyai mata pencaharian utama sebagai petani karet.

Permasalahan utama pada perkebunan karet rakyat adalah rendahnya produktivitas hasil yang disebabkan oleh rendahnya adopsi teknologi oleh petani, terutama penggunaan bahan tanam unggul, pengolahan lahan bekas kebun karet, pemupukan, dan pengendalian penyakit. Penyakit jamur akar putih (JAP) yang disebabkan oleh Rigidoporus microporus merupakan salah satu penyakit utama pada tanaman karet. Daerah yang sering mengalami serangan berat jamur akar putih di Indonesia adalah Riau, Sumatera Barat dan Kalimantan Barat, akan tetapi menurut laporan mahasiswa KKN UNIB di desa Genting Perangkap dan Desa Lubuk Balam serta bincang-bincang langsung Tim PPM dengan Kepala Desa Genting Perangkap dan Kepala Desa Lubuk Balam diketahui permasalahan utama pada tanamam karet mereka adalah penyakit jamur yang menyerang akar tananam. Penyakit jamur akar putih (JAP) menimbulkan kematian pada tanaman karet, sehingga serangan penyakit ini mengakibatkan kerugian yang cukup berarti. Berdasarkan survey lapangan Tim PPM terhadap lahan karet rakyat Desa Genting Perangkap dan Desa Lubuk Balam, banyak ditemukan jarak tanam yang sangat dekat, tunggul pohon karet yang mati diserang JAP dibiarkan begitu saja pada lahan, lalu tanaman yang mati diganti langsung dengan bibit baru tanpa membasmi habis tunggul pohon yang sudah mati oleh JAP. Akibatnya tanaman baru ini juga akan mati setelah berumur 2 tahun atau lebih, karena tertular langsung oleh jamur Rigidoporus microporus yang berasal dari tanah dan sporan jamur yang terdapat pada tunggul-tunggul pohon karet yang tidak dibersihkan. Lama kelamaan beberapa pohon yang berdekatan dengan pohon yang diserang tadi akan cepat menular terhadap beberapa pohon 
disekelilingnya karena jarak tanam yang terlalu dekat sehingga semakin mudah bersentuhan akar. Menurut hasil perhitungan Situmorang (2004) penurunan produksi karet kering terjadi rata-rata $2.7 \mathrm{~kg} /$ pohon atau $54 \mathrm{~kg} /$ pohon/20 tahun akibat serangan JAP.

Upaya pencegahan penyakit yang dianggap efektif dan sesuai bagi petani karet Desa Genting Perangkap dan Desa Lubuk Balam adalah dengan cara penggunaan fungisida kimia, namun pengendalian dengan fungisida kimia relatif sangat mahal. Akibatnya banyak para petani yang hanya menebang dan membuang tanaman yang terserang, akan tetapi cara ini juga tidak efektif karena serangan jamur akar putih ini sangat cepat menular kepada tanaman di sekitarnya. Di samping dampak penggunaan bahan kimia yang terus menerus juga memberikan efek yang tidak baik terhadap lingkungan dan kesehatan.

Beberapa hasil penelitian menunjukkan pencegahan penyakit yang efektif adalah melalui pengurangan sumber infeksi dengan mempercepat pelapukan tunggul karet dengan pembakaran atau inokulasi jamur pelapuk. Perlindungan tanaman sebelum terserang penyakit dilakukan dengan menanam tanaman antagonis lidah mertua di sekeliling pangkal batang pada awal penanaman karet (Febbiyanti, 2012). Pengobatan tanaman yang terserang JAP dengan aplikasi fungisida organik dan agent hayati jamur antagonis Trichoderma koningii (Nurhayati, 2011; Agustian dan Rachman, 2009; Djatmiko dan Rohadi, 1997). Mekanisme kerja Trichoderma spp. (salah satunya adalah Trichoderma koningii) adalah menekan perkembangan JAP dengan cara pembentukan antibiotik dan mikroparasitisme, kompetisi dan kolonisasi rizomorfa. Mekanisme penghancuran JAP terjadi melalui proses lisis miselium dan rizomorfa. Lisis merupakan proses enzimatik oleh enzim selulose yang dihasilkan oleh T. koningii. Berdasarkan analisi situasi yang telah dijabarkan diatas maka penting dilakukan kegiatan penyuluhan dan pelatihan pengendalian penyakit jamur akar putih (JAP) pada tanaman karet rakyat di Desa Genting Perangkap dan Desa Lubuk Balam dengan fungisida hayati jamur antagonis Trichoderma spp. Cara-cara pengolahan lahan bekas kebun karet terserang JAP juga akan dilatih.

Adapun yang menjadi target kegiatan ini adalah:

1. Dapat mentrasfer pengetahuan mengenai jarak tanam yang baik, penanganan lahan bekas kebun karet yang sudah mati karena serangan JAP, serta cara deteksi dini serangan JAP.

2. Dapat memberikan informasi IPTEKS terkini kepada para petani karet di Desa Genting Perangkat dan Desa Lubuk Balam tentang pemanfaatan agent pengendali hayati untuk mengendalikan penyakit yang menyerang tanaman karet, dan mampu membiakkan sendiri fungisida hayati jamur Trichoderma spp. untuk mengendalikan jamur akar putih dan penyakit tanaman karet lainnya yang disebabkan oleh jamur.

3. Masyarakat sasaran mempunyai keterampilan dalam memperbanyak biakan jamur antagonis Trichoderma spp. sehingga dapat dimanfaatkan sendiri ataupun dapat 
dikembangkan sebagai usaha sampingan penyedia jamur antagonis Trichoderma spp. untuk petani karet lainnya di Kabupaten Bengkulu Utara.

\section{METODE PENGABDIAN}

Untuk mencapai tujuan kegiatan yang diusulkan ini, digunakan metode penyuluhan, pelatihan dan aplikasi langsung ke lapangan seperti rincian berikut:

\section{Penyuluhan}

Penyuluhan diberikan tentang:

1. Penyakit-penyakit yang dapat menyerang tanaman karet sehingga diharapkan petani mampu mengenal gejala dini serangan penyakit yang umumnya berupa jamur terhadap tanaman karet.

2. Jarak tanam karet yang baik, dan penanganan lahan bekas kebun karet yang sudah mati karena serangan JAP.

\section{Pelatihan}

Kelompok petani karet akan diberi pelatihan cara pembuatan fungisida hayati jamur antagonis Trichoderma spp., sehingga diharapkan petani dapat memperbanyak dan mengembangkan sendiri jamur Trichoderma spp. yang akhirnya dapat digunakan untuk penghambat penyakit jamur akar putih (JAP).

\section{Aplikasi lapangan}

Penggunaan jamur antagonis Trichoderma spp. terhadap pohon karet yang terserang penyakit jamur akar putih dan pada proses penanaman bibit baru.

\section{HASIL DAN PEMBAHASAN}

Kegiatan PPM ini diikuti oleh 32 orang petani karet warga Desa Genting Perangkap dan Desa Lubuk Balam, Kecamatan Air Besi, Kabupaten Bengkulu Utara. Seluruh peserta mengikuti penyuluhan, pelatihan dan aplikasi/praktek lapangan dengan antusias, terlihat dari tidak adanya peserta yang meninggalkan tempat kegiatan sebelum seluruh rangkaian acara selesai.

\section{Penyuluhan tentang penyakit-penyakit yang dapat menyerang tanaman karet.}

Setelah petani karet diberi penyuluhan tentang penyakit-penyakit yang dapat menyerang tanaman karet diharapkan petani mampu mengenal gejala dini serangan penyakit yang umumnya disebabkan oleh jamur/cendawan. Penyakit utama yang menyerang tanaman karet adalah jamur akar putih (JAP), dimana gejala awal tanaman yang terserang adalah warna daun menjadi buram yang lama kelamaan menjadi kuning, akhirnya dapat mengakibatkan kematian tanaman yang diserang. Lebih parah lagi dapat menular kepada tumbuhan terdekat karena kontak akar. 
Penyuluhan tentang fungsi dan manfaat agent pengendali hayati jamur antagonis Trichoderma spp. untuk mengendalikan penyakit jamur akar putih (JAP) yang banyak menyerang perkebunan karet rakyat.

Pengendalian biologi (hayati) menunjukkan alternatif pengedalian yang dapat dilakukan tanpa harus memberikan pengaruh negatif terhadap lingkungan dan sekitarnya, salah satunya adalah dengan pemanfaatan agens hayati seperti virus, jamur atau cendawan, bakteri atau aktiomisetes. Pada kegiatan ini khalayak sasaran diperkenalkan dengan jamur antagonis Trichoderma spp. (Jayasuriya and Thennakoonm, 2007) yang mampu menghambat perkembangan patogen melalui proses mikroparasitisme, antibiosis, dan kompetisi (Rifai et al., 1996: Febbiyanti et al., 2012). Potensi jamur Trichoderma spp. sebagai jamur antagonis yang bersifat preventif terhadap serangan penyakit tanaman telah menjadikan jamur tersebut semakin luas digunakan oleh petani dalam usaha pengendalian organisme pengganggu tumbuhan (OPT). Disamping karakternya sebagai antagonis diketahui pula bahwa Trichoderm spp. juga berfungsi sebagai dekomposer dalam pembuatan pupuk organik.

Evaluasi pada tahap penyuluhan, dilihat dari tingkat khadiran khalayak sasaran dan juga dilihat dari antusiasnya mereka bertanya tentang materi penyuluhan. Seluruh peserta yang diundang datang, bahkan pesertanya menjadi bertambah dari rencana semula.

\section{Pelatihan cara pembuatan fungisida hayati jamur antagonis Trichoderma spp.}

Setelah masyarakat sasaran diberi pengetahuan tentang pengendalian hayati JAP menggunakan jamur antagonis Trichoderma spp. maka masyarakat diberi pelatihan untuk dapat memperbanyak sendiri biakan Trichoderma spp. dan mencampurkannya dengan pupuk kandang. Masyarakat kelompok sasaran pengabdian dibagi menjadi 6 kelompok kecil, setiap kelompok diberikan bahan bahan yang dibutuhkan untuk membuat fungisida hayati dari jamur Trichoderma spp. Adapun tahap-tahap perbanyakan jamur Trichoderma yang dilatih sebagai berikut:

a. Masing masing kelompok diberi tugas untuk membuat media tumbuh jamur dari beras dengan cara merendam $10 \mathrm{Kg}$ beras selama 14 jam kemudian dikukus selama 15 menit.

b. Setelah 15 menit, lalu beras diangkat dan ditempatkan pada nampan besar sampai dingin.

c. Inokulasi/penanaman bibit jamur Trichoderma spp. dengan cara masing-masing nampan ditaburi dengan 1 cawan petri inokulum Trichoderma spp. atau 2 genggam pupuk Trichoderma yang telah dibuat sebelumnya. 


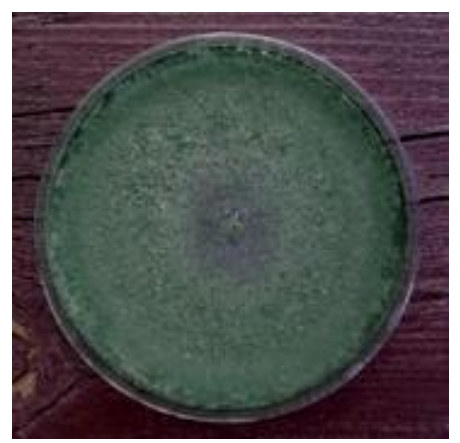

Gambar 1. Biakan Trichoderma spp.

d. Jamur yang sudah diinokulasi disimpan (diinkubasi) selama 7 hari pada suhu ruang. Amati pertumbuhan jamur Trichoderma, jamur sudah dapat dipanen setelah seluruh permukaan media telah ditumbuhi jamur Trichoderma (koloni jamur berwarna hijau).

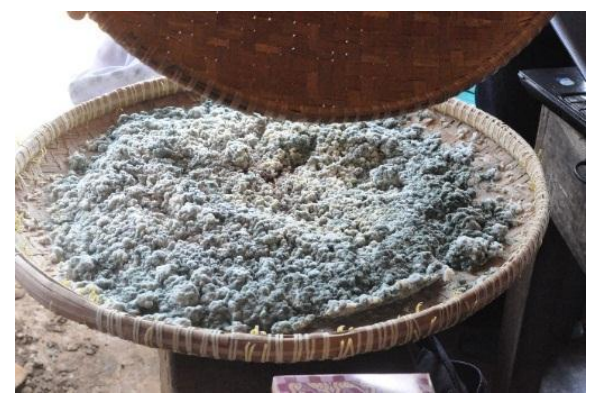

Gambar 2. Trichoderma spp. yang sudah tumbuh pada media beras, dan siap digunakan sebagai fungisida hayati pembasmi JAP.

e. Trichoderma spp. yang sudah tumbuh pada media beras sudah dapat digunakan sebagai pembasmi JAP dan sekaligus berfungsi sebagai pupuk organik. Supaya biakan jamur ini tahan disimpan selama 6 bulan maka dapat dicampur dengan tepung beras steril lalu dihaluskan.

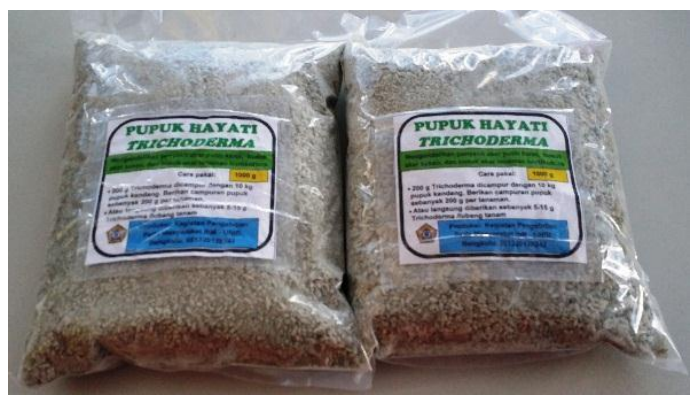

Gambar 3. Produk Trichoderma spp. yang sudah siap pakai untuk membasmi JAP dan juga siap dipasarkan kepada petani karet lainnya di wilayah Bengkulu. 
Pada tahap pelatihan ini, terlihat khalayak sasaran sangat antusias untuk mencoba dan mempraktekkan sendiri cara perbanyakan fungisida jamur Trichoderma. Semua peserta ingin mencoba cara memperbanyak bibit. Bahkan ada peserta yang ingin membuat home industri menyediakan pupuk Trichoderma untuk para petani karet di Kecamatan Air Besi. Hal ini disambut baik oleh TIM dan kami siap membina.

Evaluasi pada tahap ini adalah semua peserta harus dapat dan mampu untuk memperbanyak sendiri jamur Trichoderma serta dapat mempacking nya dengan baik untuk dapat dipasarkan kepada para petani karet lainnya di wilayah Bengkulu. Semua peserta dengan gigih dan antusias mengikuti pelatihan akhirnya mampu dan mengerti membuat fungisida dari jamur Trichoderma secara individu dan berkelompok, walaupun pada waktu produksi tahap awal masih banyak yang gagal karena adanya kontaminasi dari bakteri dan jamur lain. Berkat kegigihan peserta yang terus berlatih akhirnya berhasil memperbanyak sendiri jamur Trichoderma spp. tanpa kendala.

\section{Melakukan praktek langsung penggunaan jamur antagonis Trichoderma spp. terhadap karet masyarakat sasaran yang terkena penyakit jamur akar putih dan proses tanam bibit baru.}

Masyarakat khalayak sasaran warga petani karet Desa Genting Perangkap dan Desa Lubuk Balam dibawa terjun langsung kelapangan untuk mempraktekkan cara mengendalikan penyakit JAP mempergunakan fungisida hayati dari jamur Trichoderma spp. yang telah berhasil dibuat dan diperbanyak.

Khalayak sasaran dibawa ke lokasi perkebunan salah seorang warga Desa Genting Perangkap dan warga Desa Lubuk Balam yang paling banyak di serang JAP. Di lokasi tersebut dipilih salah satu pohon karet yang warna daunnya agak menguning yang mengindikasikan bahwa pohon karet tersebut telah diserang JAP. Untuk membuktikannya, kelompok sasaran diminta untuk menggali tunggul akarnya dan melihat dengan bantuan kaca jamur-jamur yang tumbuh dan menyerang tanaman. Ternyata memang banyak jamur Rigidoporus lignosus yang menyerang akarnya. Untuk mengobati pohon karet yang telah mulai diserang ini, khalayak sasaran kita ajarkan cara perlakuan dengan jamur Trichoderma. Akar yang telah diserang harus dibersihkan dari jamur dengan cara mengikis habis semua jamur yang menempel pada akar, lalu didekat akar ditaburkan pupuk Trichoderma yang telah dibuat tadi, setelah itu tanah ditutup kembali. Pada kesempatan ini, khalayak sasaran juga kita latih untuk menggunakan pupuk Trichoderma spp. dari awal penanaman bibit baru.

Untuk menjaga supaya tanaman tidak terserang JAP, maka harus dilakukan pemeriksaan akar satu kali setahun. Evaluasi pada tahap ini adalah semua peserta harus dapat dan mampu untuk memeriksa tanaman karet yang terserang JAP dan membasmi JAP menggunakan Trichoderma. Semua peserta pada tahap ini mampu untuk memeriksa 
tanaman yang terserang JAP dan mengendalikan serangan JAP dengan fungisida jamur Trichoderma.

\section{KESIMPULAN}

Dengan memperhatikan hasil kegiatan yang diperoleh serta hasil evaluasi pada pengabdian ini, dapat disimpulkan bahwa:

1. Masyarakat sasaran pengabdian telah mampu mengenal gejala dini serangan penyakit jamur akar putih, jarak tanam karet yang baik, serta cara penanganan lahan bekas kebun karet yang terserang JAP.

2. Masyarakat sasaran telah mengetahui cara pengendalian penyakit JAP dengan mempergunakan jamur antagonis Trichoderma spp.

3. Masyarakat sasaran sudah mempunyai keahlian dan mampu untuk memperbanyak sendiri jamur Trichoderma spp. dan cara aplikasinya terhadap tanaman yang baru ditanam, serta tanaman yang terserang JAP.

\section{UCAPAN TERIMA KASIH}

Terima kasih kepada Kementrian Ristek-Dikti atas pendanaan IbM 2015 dengan nomor kontrak: 042/SP2H/DIT.LITABMAS/II/2015.

\section{DAFTAR PUSTAKA}

Agustian, A. dan Rachman, B., 2009, Penerapan Teknologi Pengendalian Hama Terpadu Pada Komoditas Perkebunan Rakyat, Perspektif, Vol. 8, No. 1. hal: 30-41.

Buku Statistik Perkebunan, 2012.

Djatmiko, H.A., dan Rohadi, S.S., 1997, Efektivitas Trichoderma harzianum Hasil Perbanyakan dalam Sekam Padi dan Bekatul Terhadap Patogenesitas Plasmodiophora brassicae pada Tanah latosol dan Andosol. Majalah Ilmiah UNSOED, No.2, Vol. 23, hal: 10-22.

Febbiyanti, T.R., 2012, Penapisan Jamur dan Bakteri Antagonis Terhadap Jamur Akar putih

(Rigidoporus Microporus) dari Rizosfer Tanaman Lidah Mertua (Sansevieria Trifasciata Prain), Jurnal Penelitian Karet, No. 1, Vol. 30.

Gubernur Bengkulu, 2012, Rencana Kerja Pemerintah Daerah, Bengkulu.

Jayasuriya, K.E. and Thennakoonm, B.I., 2007, Biological Control of Rigidoporus microporus,

The Cause of White Root Disease in Rubber, J. Bio. Sci., 36 (1), p: 9-16.

Muhammad, A., Shadi, A., Harahap, J., Wildan, M., Arini, M.A.D., Gusliana, S., dan Febrina, Y., 2012, Laporan Akhir Kuliah Kerja Nyata Mahasiswa UNIB Periode 67. P3KKN, Lembaga Pengabdian Pada Masyarakat, Universitas Bengkulu. 
Nurhayati, 2011, Penggunaan Jamur dan Bakteri dalam Pengendalian Penyakit Tanaman Secara Hayati yang Ramah Lingkungan, Prosiding Semirata Bidang Ilmu-ilmu Pertanian BKS-PTN Wilaya Barat.

Rifai, M., Mujim, S., dan Aeny, T.N., 1996, Pengaruh Lama Investasi Trichoderma viride Terhadap Intensitas Serangan Pythium sp. pada Kedelai, Jurnal Penelitian Pertama, No. VII, Vol. 8, hal: 20-25.

Situmorang, A., 2004, Status dan Manajemen Pengendalian Jamur Akar Putih di Perkebunan Karet, Prosiding Pertemuan Teknis, Pusat Penelitian Karet, Balai Penelitian Sembawa, hal: 66-86. 

